\title{
Pengaruh Waktu Penyimpanan Antisera Terhadap Daya Aglutinasi Metode Slide
}

\author{
Raehun $^{1}$, Yunan Jiwintarum ${ }^{2}$, Iswari Pauzi ${ }^{3}$ \\ 1,2,3 Jurusan Analis Kesehatan, Poltekkes Kemenkes Mataram, Indonesia
}

\begin{tabular}{l} 
Article Info \\
Article history: \\
Received Februari 15 $5^{\text {th }}, 2019$ \\
Revised Februari $22^{\text {nd }}, 2019$ \\
Accepted March $1^{\text {st }}, 2019$ \\
\hline
\end{tabular}

Keyword:

Time of Storage

Antisera

Agglutination Power

\begin{abstract}
Background: Storage of reagents must be very noted in order to get accurate results. Blood type antisera is a reagent for blood type checking slide method, as an alternative reagent can be used by human serum. Both serum or plasma must be immediately separated from the blood cells and immediately used or stored for a certain period of time so that the antibody content in the serum remains in the optimal state when used. Storage at room temperature $\left(15-25^{\circ} \mathrm{C}\right)$ for 4 hours practically does not change metabolites, enzymes and electrolytes.
\end{abstract}

Objective: To determine the effect of antisera storage time on the agglutination power of the slide method.

Method: This study is a Quasi Experimental Design. The number of treatment samples is 4 with replication 6 times so that it becomes 24 experimental units. Data analysis was carried out descriptively, data collected in the form of agglutination power grade data slide method by using antisera from serum as reagent.

Results: Agglutination power at 0 days, 2 days and 4 days of antisera storage was obtained +4 , antisera storage at 6 days caused a change in agglutination power to +3 .

Conclusion: There is an effect of antisera storage time on the slide method agglutination power on the sixth day of storage.

\begin{abstract}
ABSTRAK
Latar belakang: Penyimpanan reagen harus sangat diperhatikan agar mendapatkan hasil yang akurat. Antisera golongan darah merupakan reagen untuk melakukan pemeriksaan golongan darah metode slide, sebagai reagen alternatif dapat digunakan serum manusia. Baik serum atau plasma harus segera dipisahkan dari sel-sel darah dan segera digunakan atau disimpan dalam jangka waktu tertentu agar kandungan antibodi dalam serum tetap dalam keadaan optimal saat digunakan. Penyimpanan pada suhu ruang $\left(15-25^{\circ} \mathrm{C}\right)$ selama 4 jam praktis tidak mengubah metabolit, enzim-enzim dan elektrolit-elektrolit.

Tujuan: Untuk mengetahui pengaruh waktu penyimpanan antisera terhadap daya aglutinasi metode.

Metode: Penelitian ini merupakan penelitian Eksperimen Semu (Quasi Eksperimental Design). Jumlah perlakuan sampel adalah 4 dengan replikasi sebanyak 6 kali sehingga menjadi 24 unit percobaan. Analisis data dilakukan secara deskriptif, data yang dikumpulkan berupa data grade daya aglutinasi metode slide dengan menggunakan antisera dari serum sebagai reagen.

Hasil: Didapatkan hasil daya aglutinasi pada 0 hari, 2 hari dan 4 hari penyimpanan antisera adalah +4 , penyimpanan antisera pada 6 hari menyebabkan terjadinya perubahan daya aglutinasi menjadi +3 .

Kesimpulan: Ada pengaruh waktu penyimpanan antisera terhadap daya aglutinasi metode slide pada hari keenam penyimpanan.
\end{abstract}




\section{Kata Kunci: Waktu Penyimpanan, Antisera dan Daya Aglutinasi.}

Copyright () Jurnal Analis Medika Bio Sains

\section{Pendahuluan}

Pengendalian mutu internal mencakup tahap pra analitik, analitik dan pasca analitik. Tahap pra analitik meliputi persiapan sampel, penyimpanan sampel, persiapan kertas kerja. Tahap analitik meliputi pengolahan sampel dan kalibrasi alat. Tahap pasca analitik meliputi pencatatan hasil dan pelaporan ${ }^{1}$

Faktor yang perlu diperhatikan dalam laboratorium adalah faktor pra analitik yaitu perbedaan interval waktu pemeriksaan atau penggunaan dari satu sampel (serum). Selain itu juga pengaruh suhu di sekitar serum yang dapat mempengaruhi senyawa-senyawa kimiawi didalamnya selama menunggu untuk diperiksa atau digunakan ${ }^{2}$.

Pemeriksaan golongan darah dilakukan dengan melakukan pengujian aglutinasi atau penggumpalan darah terhadap antigen yang didifusikan dalam cairan sel darah merah. Umumnya penentuan golongan darah $\mathrm{ABO}$ ialah dengan menggunakan metode slide, metode slide merupakan salah satu metode yang sederhana, cepat dan mudah untuk pemeriksaan golongan darah $^{3}$. Aglutinasi adalah penggumpalan sel darah merah yang disebabkan oleh ikatan antibodi dengan antigen pada sel darah merah sehingga menghasilkan ikatan yang menggandeng beberapa sel secara bersama-sama ${ }^{4}$.

Prinsip pemeriksaannya adalah apabila sel darah merah mengandung antigen yang sesuai dengan jenis antibodi yang ditambahkan pada reagen antisera, maka akan terjadi aglutinasi.

Terjadinya aglutinasi dibaca secara visual

sehingga kemungkinan terjadi kesalahan pembacaan hasil lumayan tinggi tergantung dari kekuatan aglutinasi. Kekuatan atau daya reaksi aglutinasi yang dihasilkan pada pemeriksaan golongan darah dipengaruhi oleh kemampuan dari antisera (antibodi) berikatan atau bereaksi dengan sel darah merah (antigen). Faktor-faktor yang mempengaruhi reaksi tersebut diantaranya, muatan ion sel darah merah, suhu, $\mathrm{pH}$, kesegaran serum dan sel-sel darah merah, rasio antibodi terhadap antigen dan kekuatan ion ${ }^{5}$.

Berdasarkan penelitian terdahulu serum dapat dijadikan sebagai antisera untuk pemeriksaan golongan darah yakni dengan menggunakan serum manusia sesuai dengan golongan darahnya, untuk golongan darah $\mathrm{A}$ maka akan didapatkan antisera $\mathrm{B}$, untuk golongan darah B maka akan didapatkan antisera A. Peneliti sebelumnya hanya pernah menguji apakah serum bisa digunakan sebagai antisera alternatife atau tidak, namun belum pernah ada yang melakukan penelitian mengenai faktorfaktor yang dapat mempengaruhi hasil aglutinasi dalam metode slide ini. Oleh karenanya berdasarkan faktor-faktor yang dapat mempengaruhi kekuatan atau daya aglutinasi yang diuraikan diatas, dimana salah satunya ialah kesegaran serum (penyimpanan serum) maka peneliti ingin mengetahui pengaruh waktu penyimpanan antisera terhadap daya aglutinasi pada metode slide ${ }^{4}$. 


\section{Metode Penelitian}

Penelitian ini bersifat Eksperimen Semu (Quasi Eksperimental Design), yaitu penelitian yang bertujuan untuk mengetahui suatu gejala atau pengaruh yang timbul sebagai akibat dari adanya perlakuan waktu penyimpanan antisera terhadap daya aglutinasi metode slide ${ }^{6}$. Penelitian ini ialah dengan adanya perlakuan, penggunaan kontrol dan pengulangan atau replikasi. Adapun perlakuannya ialah pada 0 hari penyimpanan, 2 hari penyimpanan, 4 hari penyimpanan dan 6 hari penyimpanan. Data hasil penelitian dianalisis secara deskriptif untuk mengetahui pengaruh waktu penyimpanan antisera terhadap daya aglutinasi metode slide.

\section{Hasil Penelitian dan Pembahasan}

Hasil penelitian pengaruh waktu penyimpanan antisera terhadap daya aglutinasi metode slide dapat dilihat pada tabel dibawah ini :

Tabel 4.1 Hasil pengukuran daya aglutinasi pada metode slide

\begin{tabular}{ccccc}
\hline No & \multicolumn{4}{c}{ Hasil Daya Aglutinasi } \\
\cline { 2 - 5 } sampel & T0 & T1 & T2 & T3 \\
& 0 & 2 & 4 & 6 \\
& Hari & Hari & Hari & Hari \\
\hline A1 & +4 & +4 & +4 & +3 \\
\hline A2 & +4 & +4 & +4 & +3 \\
\hline A3 & +4 & +4 & +4 & +3 \\
\hline A4 & +4 & +4 & +4 & +3 \\
\hline A5 & +4 & +4 & +4 & +3 \\
\hline A6 & +4 & +4 & +4 & +3 \\
\hline
\end{tabular}

Tabel 4.1 menunjukan daya aglutinasi pada

masing-masing waktu penyimpanan, didapatkan

hasil perubahan daya aglutinasi adalah terjadi

pada hari ke enam penyimpanan antisera.

Pada penelitian ini digunakan reagen alternatif antisera yakni dari serum manusia.
Pembuatan antisera A adalah dari dari sampel bergolongan darah B yang diputar (sentrifuge) pada kecepatan 3000 rpm selama 5 menit. Serum adalah cairan bening yang dipisahkan dari sel-sel darah menggunakan sentrifuge. Pada penelitian ini dilakukan uji ketahanan serum yang disimpan terhadap daya aglutinasi metode slide dengan cara disimpan dalam waktu tertentu pada suhu ruang $\left(15-25^{\circ} \mathrm{C}\right)$ yakni $20^{\circ} \mathrm{C}$. Adapun hal yang perlu diperhatikan dalam penyimpanan sampel yaitu : waktu dan suhu penyimpanan sampel, serta cara penanganan sampel ${ }^{4}$.

Serum tidak memiliki faktor pembekuan karena diperoleh dari darah yang dibiarkan membeku. Serum harus segera dipisahkan dari bahan bekuan darah dalam sampel atau paling lambat 2 jam setelah pengambilan darah untuk menghindari perubahan-perubahan dari zat yang terlarut didalamnya (termasuk protein) oleh pengaruh hemolisis serum. Sampel serum harus segera disimpan dalam lemari es suhu $4^{\circ} \mathrm{C}$, serta selama proses penyimpanan serum dimasukan dalam tabung kering dan bersih serta ditutup rapat menggunakan parafin atau menggunakan wadah tertutup supaya stabilitas sampel serum tidak berubah terutama struktur protein yang ada dalam sampel, penyimpanan serum suhu $-20^{\circ} \mathrm{C}$ dapat menyebabkan serum membeku dan siklus beku cair dapat menyebabkan terjadinya kerusakan struktur protein dalam serum, serum yang beku harus dicairkan dan diletakkan dalam suhu ruang selama 1 jam, penyimpanan pada suhu ruang (15$25^{\circ} \mathrm{C}$ ) harus segera dilakukan pemeriksaan, agar kandungan serum termasuk jumlah antbodi tidak berubah akibat terdeteksinya perubahan konsentrasi protein dan mengubah proporsi protein menjadi lebih rendah selama penyimpanan ${ }^{1}$. 
ISSN: 2656-2456 (Online)

ISSN: 2356-4075 (Print)

\begin{abstract}
Pada hasil penelitian didapatkan perubahan hasil daya aglutinasi pada hari keenam menjadi +3 , hal ini adalah karena terjadinya perubahan jumlah antibodi (rasio antibodi) karena serum yang tidak segera digunakan dapat mengakibatkan rusaknya struktur protein sehingga akan menyebabkan penurunan jumlah protein termasuk ratio atau jumlah antibodi itu sendiri. Oleh karenanya daya aglutinasi antara antigen dan antibodinya pun berkurang sehingga akan mempengaruhi hasil pembacaan. Berdasarkan hal ini, maka untuk pemeriksaan laboratorium yang memanfaatkan reaksi antara antigen dan antibodi secara metode slide maka haruslah diperhatikan waktu penyimpanan serum, agar didapatkan hasil pembacaan yang valid.
\end{abstract}

\section{Kesimpulan}

Berdasarkan hasil penelitian yang telah dilakukan maka didapatkan kesimpulan ada pengaruh waktu penyimpanan antisera terhadap daya aglutinasi metode slide pada hari keenam penyimpanan.

\section{Daftar Pustaka}

1. Nur Alifa, E., Santosa, B., \& Anggraini, H.
(2012).Perbedaan Kadar Asam Urat Berdasarkan Waktu Penyimpanan Serum Selama 0 Jam, 72 Jam dan 96 Jam Pada Suhu Ruang. Retrieved from http://repository.unimus.ac.id

2. Santi, O. D., Rosita, L., \& Cahyaningrum, Y. D. (2011). Pengaruh Suhu dan Interval Waktu Penyimpanan Sampel Serum pada Pengukuran Kadar Glukosa Darah. JKKI.

3. Anita, O., \& Silvia, N. D. (2016). Pemeriksaan Golongan Darah Sistem ABO Metode Slide dengan Reagen Serum Golongan Darah ABO. Jurnal Teknologi Laboratorium.

4. Mulyantari, N. K., \& Yasa, I. P. S. (2017). Laboratorium Pratransfusi Up Date. Denpasar: Udayana University Press Kampus Universitas Udayana Denpasar.

5. Naim, N. (2015). Pengaruh variasi pengenceran antisera terhadap hasil pemeriksaan golongan darah abo landstainer. Media Analis Kesehatan.

6. Notoatmodjo, S. (2010). Metodologi Penelitian Kesehatan. Jakarta: PT. Rineka Cipta. 